\title{
Nutrient digestibility and changes in feeding behavior of cattle fed cottonseed and
}

\section{vitamin $\mathrm{E}$}

\author{
Ricardo Galbiatti Sandoval Nogueira*(), Flavio Perna Junior ${ }^{\circledR}$, Angélica Simone Cravo Pereira ${ }^{\circledR}$, Paulo Henrique Mazza Rodrigues ${ }^{\circledR}$
}

Universidade de São Paulo/FZEA - Depto. de Nutrição e Produção Animal, Av. Duque de Caxias Norte, 225 - 13653900 - Pirassununga, SP - Brasil.

*Corresponding author <rick_galbiatti@hotmail.com>

Edited by: Gerson Barreto Mourão

Received May 06, 2017

Accepted October 31, 2017

\begin{abstract}
High lipid concentration in ruminant diets often harms nutrient digestibility and feed intake; thus, a protected lipid and antioxidant source can be considered as an alternative for improving diet energy without putting animal production at a disadvantage. The aim of this study was to evaluate the dry matter intake (DMI), nutrient digestibility and feeding behavior of cattle fed cottonseed and vitamin E. Six cannulated cows, non-pregnant, non-lactating were distributed in a replicated $3 \times 3$ Latin Square design. Feed was offered ad libitum twice daily. Treatments were: 1) Control, 2) CS: $30 \%$ cottonseed included; and 3) CSVitE: $30 \%$ cottonseed plus $500 \mathrm{IU}$ VitE included. Data were analyzed by SAS (Statistical Analysis System, v.9.3) and the significance was declared at $p<0.05$. Diets with cottonseed had $22 \%$ greater digestibility of ether extract and $9 \%$ lower digestibility of non-fiber-carbohydrates compared to the control. Treatments with cottonseed had $13 \%$ higher time eating, $48 \%$ more ruminating, $34 \%$ more chewing and $17 \%$ lower time idling compared to the control. Molar proportion of propionate was $36 \%$ higher and the butyrate and acetate:propionate ratio were $27 \%$ and $30 \%$ lower, respectively, for the cottonseed treatments compared to the control. Including cottonseed up to $30 \%$ can be used to increase diet energy density leading to improvements in feeding behavior and ruminal parameters. The inclusion of Vitamin $E$ did not result in benefits to cattle when it was combined with cottonseed. Further studies should be undertaken to evaluate vitamin $E$ levels in association with different amounts and lipid sources.
\end{abstract}

Keywords: antioxidant, oilseed, ruminant

\section{Introduction}

High-producing cattle have high energy requirements and the supplementing of lipids is a common practice for increasing energy density in the feed of highproducing cattle (Kargar et al., 2010). However, higher concentrations of lipids often exert detrimental effects on the digestibility of nutrients (Patra et al., 2013). In addition, adding lipid affects the ruminal disappearance rate, which could affect feeding behavior (Harvatine and Allen, 2005).

Oil in seeds is stored intracellularly, and the release of lipids is slower compared with feeding oil directly (Steele et al., 1971). Oilseed has the additional benefit of lessening the detrimental effect of fat on digestion (Zakrys et al., 2008). Cottonseed is an oilseed from a by-product of the cotton industry. Cottonseed oil has $70 \%$ unsaturated fatty acids (Keele et al., 1989), and high levels of unsaturated fatty acids may have a negative effect on DMI and fiber digestion (Martinez et al., 1991; DePeters and Cant, 1992). In addition, dietary lipids, such as supplemental fat rich in unsaturated fatty acids, if not biohydrogenated, can be significant contributors to the free radical load in animals (Vásquez-Anón and Jenkins, 2007). This results in the consequential release of free radicals in the rumen (Wey et al., 2015) and excesses of free radicals in the rumen affect microorganism activity and growth with negative consequences for nutrient digestibility (Wey et al., 2015).
Vitamin E is known as a scavenger of free radicals and has protective effects against oxidative damage (Putnam and Comben, 1987). It could be beneficial to rumen microbes and, consequently, improve rumen fermentation and nutrient digestibility. According to Hino et al. (1993) and Vásquez-Anón and Jenkins (2007), adding antioxidants minimizes the effect of a supplementation of a high level of unsaturated fatty acids on rumen fermentation and nutrient digestibility.

However, no in vivo studies have been carried out to evaluate whether an oilseed in association with an antioxidant would increase nutrient digestibility with consequences for the feeding behavior. Therefore, we hypothesized that an oilseed could decrease the negative effects of fatty acids in the rumen and the association between an oilseed and an antioxidant would improve the ruminal fermentation. The overall aim of this research was to investigate the effects of cottonseed and the inclusion of vitamin $\mathrm{E}$ on intake, digestibility and excretion of nutrients, ruminal dynamics and the feeding behavior of cows.

\section{Materials and Methods}

\section{Study Location and ethical issue}

The study was conducted at Pirassununga, in the state of Sao Paulo, Brazil (21 ${ }^{\circ} 59^{\prime} 46^{\prime \prime}$ S; $47^{\circ} 25^{\prime} 33^{\prime \prime} \mathrm{W}$ and $625 \mathrm{~m})$. The experiment was approved by and complied with the guidelines set out by the Ethics Committee in the Use of Animals code of the University of São Paulo, 
under application number $n^{\circ} 009 / 2013$, in respect of animal experimentation and care of animals used for scientific purposes.

\section{Animal housing and feeding}

Six Holstein cows, not pregnant and non-lactating, with rumen fistula and average body weight of $876 \mathrm{~kg}$ $( \pm 16.1)$ were housed in individual pens with free access to water and sand bedded stalls. Animals were fed ad libitum twice daily (08h00 and 16h00). Feed was weighed daily and offered to each animal after feed residue from the previous day had been removed. The vitamin E amount was weighed daily so as to offer 500 IU per animal per day. Vitamin E was included according to Secrist et al. (1997) who stated that mean feed efficiency improvements indicate that vitamin E supplementation of cattle diets at 500 IU daily should be economically justified. The vitamin E source was $50 \%$ alpha tocopheryl acetate. Orts were recorded once daily and the feeding rate was adjusted to yield orts on the basis of at least $5 \%$ of the amount supplied (on an as-fed basis). The animals were weighed individually on the initial and final day of each experimental period.

\section{Experimental design and treatment}

The experimental design was a replicated $3 \times$ 3 Latin Squared design with three periods, each experimental period consisting of 21 days. Three dietary treatments were as follows - 1) Control: diet without treatment; 2) CS: diet supplemented with $30 \%$ of cottonseed and 3) CSVitE: diet supplemented with $30 \%$ of cottonseed plus $500 \mathrm{IU}$ of vitamin E. The ingredients and chemical composition of the experimental diets are given in Table 1.

\section{Sampling schedule}

The trial consisted of three experimental periods, each lasting 21 days. The first 10 days of each period were used for adaptation. The $11^{\text {th }}$ to $15^{\text {th }}$ days were used for obtaining DMI. The $15^{\text {th }}$ day was used for feeding behavior, and the $16^{\text {th }}$ for $\mathrm{pH}$ evaluation. The $11^{\text {th }}$ to $18^{\text {th }}$ days were used for nutrient digestibility, external marker and feces collection. On the $18^{\text {th }}$ day ruminal samples were collected to determine the ruminal short chain fatty acids (SCFA) concentration. The $20^{\text {th }}$ to $21^{\text {th }}$ days were used for ruminal dynamic information.

\section{Feed intake}

Feed intake was determined between days 11 to 15 of each period by weighing feeds offered to animals and refusals. During this period, feed ingredients were collected, sampled and stored at $-20^{\circ} \mathrm{C}$.

\section{Ruminal dynamics}

The last two days of each period, before morning feeding, when the rumen is theoretically at its lowest volume, and three hours after morning feeding, when the rumen theoretically reaches its greatest volume,
Table 1 - Ingredients and chemical composition of dietary treatments.

\begin{tabular}{|c|c|c|c|}
\hline & \multicolumn{3}{|c|}{ Dietary treatments } \\
\hline & Control & CS & CSVitE \\
\hline \multicolumn{4}{|l|}{ Ingredient } \\
\hline Sugarcane bagasse ( $\mathrm{g} \mathrm{kg}^{-1}$ of DM) & 134 & 134 & 134 \\
\hline Cottonseed (g kg-1 of DM) & - & 304 & 304 \\
\hline Ground corn grain ( $\mathrm{g} \mathrm{kg}^{-1}$ of DM) & 572 & 281 & 281 \\
\hline Citrus polp (g kg-1 of DM) & 183 & 183 & 183 \\
\hline Soybean meal, ( $\mathrm{g} \mathrm{kg}^{-1}$ of DM) & 817 & 817 & 817 \\
\hline Minerals ( $\mathrm{g} \mathrm{kg}^{-1}$ of DM) & 60 & 60 & 60 \\
\hline Limestone ( $\mathrm{g} \mathrm{kg}^{-1}$ of DM) & 40 & 40 & 40 \\
\hline Urea (g kg-1 of DM) & 13.7 & 2.7 & 2.7 \\
\hline Vitamin $\mathrm{E}$ (mg kg-1 of DM) & - & - & 500 \\
\hline \multicolumn{4}{|l|}{ Chemical composition } \\
\hline $\mathrm{DM}\left(\mathrm{g} \mathrm{kg}^{-1}\right)$ & 891 & 910 & 910 \\
\hline $\mathrm{CP}\left(\mathrm{g} \mathrm{kg}^{-1}\right.$ of DM) & 158 & 160 & 160 \\
\hline $\mathrm{EE}$ ( $\mathrm{g} \mathrm{kg}^{-1}$ of $\left.\mathrm{DM}\right)$ & 26.1 & 76.9 & 76.9 \\
\hline NDF ( $\mathrm{g} \mathrm{kg}^{-1}$ of DM) & 234 & 357 & 357 \\
\hline ADF $\left(\mathrm{g} \mathrm{kg}^{-1}\right.$ of $\left.\mathrm{DM}\right)$ & 171 & 265 & 265 \\
\hline Lignin (g kg-1 of DM) & 55.3 & 136 & 136 \\
\hline $\mathrm{Ca}\left(\mathrm{g} \mathrm{kg}^{-1}\right.$ of DM) & 15.7 & 18.2 & 18.2 \\
\hline$P\left(\mathrm{~g} \mathrm{~kg}^{-1}\right.$ of $\left.\mathrm{DM}\right)$ & 12.7 & 14.7 & 14.7 \\
\hline Hemicellulose ${ }^{1}\left(\mathrm{~g} \mathrm{~kg}^{-1}\right.$ of DM) & 63 & 92 & 92 \\
\hline Cellulose $^{2}\left(\mathrm{~g} \mathrm{~kg}^{-1}\right.$ of DM) & 115 & 136 & 136 \\
\hline $\mathrm{OM}^{3}\left(\mathrm{~g} \mathrm{~kg}^{-1}\right.$ of $\left.\mathrm{DM}\right)$ & 829 & 845 & 845 \\
\hline $\mathrm{NFC}^{4}\left(\mathrm{~g} \mathrm{~kg}^{-1}\right.$ of DM) & 525 & 328 & 328 \\
\hline Gross energy (MJ kg-1 of DM) & 17.4 & 17.9 & 17.9 \\
\hline Vitamin $\mathrm{E}^{5}\left(\mathrm{mg} \mathrm{kg}^{-1}\right.$ of DM & 14.0 & 7.00 & 507 \\
\hline \multicolumn{4}{|c|}{$\begin{array}{l}\mathrm{DM}=\text { dry matter; } \mathrm{CP}=\text { crude protein; } \mathrm{EE}=\text { ether extract; NDF = neutral } \\
\text { detergent fiber; } \mathrm{ADF}=\text { acid detergent fiber; } \mathrm{Ca}=\text { calcium; } \mathrm{P}=\text { phosphorus; } \\
\mathrm{OM}=\text { organic matter; NFC = Non-fibrous carbohydrate; } \mathrm{MJ}=\text { mega Joule; } \\
{ }^{1} \mathrm{Hemicelllulose}: \mathrm{NDF}-\mathrm{ADF} ;{ }^{2} \text { Cellulose }=\mathrm{ADF}-\text { Lignin; }{ }^{3} \mathrm{OM}=\mathrm{DM} \text {-mineral; } \\
\text { }{ }^{\mathrm{N}} \mathrm{NFC}=100-\left(\mathrm{CP}+\mathrm{NDF}+\mathrm{EE}+\text { ash); }{ }^{5} \text { Vitamin } \mathrm{E}=\text { estimated according to }\right. \\
\mathrm{NRC}(2001) \text {. }\end{array}$} \\
\hline
\end{tabular}

ruminal digesta was manually removed from each cow through rumen cannula to determine the solid disappearance rate in the rumen as described by Dado and Allen (1995). The ruminal digesta was separated, manually through a screen into solid and liquid content, and then each one was weighed and sampled. Immediately after this, the ruminal digesta was placed in the rumen. Solid and liquid content samples were dried at $60{ }^{\circ} \mathrm{C}$ (forced-air oven) for 72 hours to determine dry matter content. To determine ruminal solid mass and ruminal liquid mass the solid and liquid contents weighed previously were adjusted by the respective dry matter (DM) content. The DM disappearance rate was considered equal to the intake rate, and they were estimated using equations 1 and 2 (Robinson et al., 1987):

$S D(\%$ hour $)=100 \times \frac{\text { Daily DM intake }(\mathrm{kg})}{\text { Ruminal Solid Mass }(\mathrm{kg})} \div 24$

$S D(\mathrm{~kg} \mathrm{~h})=$ Ruminal Solid Mass $(\mathrm{kg}) \times \frac{S D(\% \text { hour })}{100}$

where: $S D=$ olid disappearance rate. 


\section{Feeding behavior}

Eating, ruminating and idling activities, measured in minutes, were monitored each period visually over a 24-h period. Animals were considered to be engaged in eating activity when they had their head in the feed bunk and were in contact with the diet. Rumination time included regurgitation, re-mastication, and re-swallowing. Idling time included periods during which the animals slept, lay down, walked or stood idly by.

Activities were noted every five $\mathrm{min}$, and each behavior was assumed to persist for the entire 5-min interval. Total chewing time was calculated as the sum of eating and ruminating time (Maekawa et al., 2002). A meal or bout was defined as a minimum sequence of two activities of the same behavior. The time spent

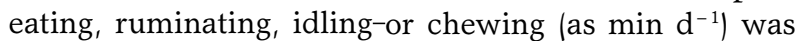
calculated as the sum of total activities. Length, as min meal $^{-1}$ or min bout ${ }^{-1}$, was calculated by the division between time spent in each behavior and number of meals or bouts.

The intake of DM and neutral detergent fiber (NDF) were used to calculate the amount of these components eaten, ruminated or chewed, expressed in kilograms per minute ( $\mathrm{kg} \mathrm{DM}$ or NDF $\mathrm{min}^{-1}$ ) or kilograms per bout (kg DM or NDF bout $\left.{ }^{-1}\right)$. Kilogram per minute was determined by DM or NDF intake divided by total time eaten, ruminated or chewed. Kilograms per bout was determined by DM or NDF intake divided by amount of bouts per day of eating, ruminating and chewing as described by Burger et al. (2000).

\section{Nutrient digestibility}

Total tract nutrient digestibility was determined using chromium oxide. From the $9^{\text {th }}$ until the $18^{\text {th }}$ of every month, $15 \mathrm{~g}$ head $\mathrm{d}^{-1}$ of indigestible marker were placed twice daily ( $08 \mathrm{~h} 00$ and $16 \mathrm{~h} 00$ before feeding) via rumen fistula each day. Feces were collected, rectally, twice daily, from the $14^{\text {th }}$ until the $18^{\text {th }}$ at $08 \mathrm{~h} 00$ and $16 \mathrm{~h} 00$ after feeding. A sample blend of $200 \mathrm{~g}$ samples were then analyzed for chromium oxide concentration according to Conceição et al. (2007). DM digestibility (\%) was calculated by equation 3 as follows:

Digestibility $(\%)=100-\left(\frac{[\text { ] chromium diet }(\%)}{[\text { ] chromium feces }(\%)}\right) \times 100$

where: [ ] chromium diet: concentration of chromium in the diet (total chromium added divided by total DMI); [ ] chromium feces: concentration of chromium in the feces.

Nutrient digestibility in percentage was calculated by equation 4 as follows:

Nutrient dig. $(\%)=100-(D M$ digestibility $) \times\left(\frac{[\text { ]nutrient feces }(\%)}{[\text { ] } \text { nutrient inake }(\%)}\right) \times 100$

where: nutrient dig. (\%):digestibility of nutrients; nutrient feces (\%): concentration of nutrient in the feces; [ ] nutrient intake (\%): concentration of nutrient intake in relation to DMI.
Fecal output, expressed as kg (DM basis), was calculated as in equation 5 as follows:

Fecal output $(\mathrm{kg})=\frac{(100-\text { mutrient digestibility }) \times \text { nutrient inake }(\mathrm{kg})}{100}(5)$

\section{pH evaluation}

Ruminal $\mathrm{pH}$ was obtained using a data logger, Attached to the data logger were 2 weights of 900 grams each to maintain position in the rumen ventral sacral. Meters of $\mathrm{pH}$ unit were calibrated to $\mathrm{pH} 7.0$ and 4.0 every time before being put into the rumen fluid. During each 24 hour period, $\mathrm{pH}$ was measured each $10 \mathrm{~min}$. Data were uploaded to a computer and an Excel program was used to arrange data.

\section{Short chain fatty acid concentration}

Ruminal content samples were collected on the18th day of each period through the ruminal cannula at $0,3,6,9$ and $12 \mathrm{~h}$ after the morning meal. On this day, animals were fed once in the morning. Approximately $300 \mathrm{~mL}$ of rumen fluid (using a motorized vacuum pump) and $300 \mathrm{~g}$ of solid content (with hands) were collected at each sampling time from three different parts of the rumen (dorsal sac in the front, middle and back). The two fractions were mixed in the proportion of $66 \%$ liquid phase and $33 \%$ solid phase and homogenized before preparation for analysis of SCFA. For SCFA analyses which included acetate, propionate and butyrate, a fraction of approximately 50 $\mathrm{mL}$ of ruminal fluid was centrifuged at $2000 \times \mathrm{g}$ for 15 $\mathrm{min}$, and $2 \mathrm{~mL}$ of the supernatant was added to $0.4 \mathrm{~mL}$ of formic acid and then frozen at $-20{ }^{\circ} \mathrm{C}$ during the night. On the following day, $2 \mathrm{~mL}$ of each sample were placed in centrifuge tubes and centrifuged at $5000 \times \mathrm{g}$ for $15 \mathrm{~min}$. After that, $1 \mathrm{~mL}$ was placed in a vial for the determination of SCFA. SCFA were measured by gas chromatography, at room temperature $\left(25^{\circ} \mathrm{C}\right)$, in accordance with Erwin et al. (1961), using a glass column of $2 \mathrm{~m}$ of length and $1 / 8^{\prime \prime}$ internal diameter that was packed with 80/120.

\section{Laboratory Analyses}

Individual feed ingredients and orts were collected for each period and composited in representative samples on an equal-weight basis. Samples were dried at $60{ }^{\circ} \mathrm{C}$ (forced-air oven) for 48 hours and ground to pass through a 1-mm Wiley mill screen and analyzed for $105^{\circ} \mathrm{C} \mathrm{DM}$, organic matter $(\mathrm{OM})$, crude protein $(\mathrm{CP})$, ether extract (EE) and NDF according to AOAC. (1995). $\mathrm{DM}$ concentration was determined at $105^{\circ} \mathrm{C}$ for 4 hours (method 930.15; AOAC, 1995) followed by cold weighing. Organic Matter was determined by ashing the samples at $550{ }^{\circ} \mathrm{C}$ for 5 hours (method 942.05; AOAC, 1995). Nitrogen content was determined by the micro Kjeldahl (AOAC, 1995) method and was multiplied by 6.25 to determine CP. Ether extract was determined using light petroleum ether in the Soxhlet apparatus (method 920.39; AOAC, 1995). NDF, acid detergent fiber (ADF), and lig- 
nin were measured using the sequential method, as described by Van Soest et al. (1991). Phosphorus and calcium were determined by atomic absorption spectroscopy adapted from method $7000^{a}$ EPA (1992).

\section{Statistical analyses}

The data were analyzed using the MIXED procedure of SAS (Statistical Analysis System, version 9.3) with animals within a defined period as the experimental unit. The model included the fixed effect of treatment and random effect square, period, and animals within the square. These variables were analyzed using the following model:

$Y_{i j k l}=\mu+T_{i}+P_{j}+S_{k}+A_{l}\left(S_{k}\right)+e_{i j k l}$

where: $Y_{i j k l}=$ the dependent response variable, $\mu=$ the overall mean, $T_{i}=$ the treatment effect, $P_{j}=$ the period effect, $S_{k}=$ the square effect, $A_{1}\left(S_{k}\right)=$ the animals within square effect and $e_{i j k l}$, the residual error term.

Short chain fatty acids ruminal concentration was analyzed according to the procedure for linear mixed models (PROC MIXED), and the period was the repeated variable. Among 15 different covariance structures tested, the model used was chosen based on the lower value of Corrected Akaike Information Criterion (AICC) (Wang and Goonewardene, 2004). In the model, the treatment, time and interaction treatment*time effects were considered fixed and the effects of period, square and animal within the square were considered random. For mean comparison between treatments the PDIFF test was used.

Contrast statements were used to evaluate differences between means of control vs. CS plus CSVitE (C1) as well as between CS vs. CSVitE (C2). The statistical significance was declared at $p<0.05$.

\section{Results}

\section{Nutrient intake, excretion and digestibility}

Total DM intake, expressed in kilograms per day, in percentage of $\mathrm{BW}$ or $\mathrm{g} \mathrm{kg}^{-1}$ of metabolic weight, was similar ( $p>0.05$ for Treat) for animals fed with the control, CS or CSVitE. Adding cottonseed to diets, regardless of vitamin $\mathrm{E}$ inclusion, increased dietary intake of EE by $306 \%$, NDF by $123 \%$ and ADF by $58 \%$, and also decreased dietary intake of non-fibrous carbohydrate (NFC) by $44 \%$ ( $p<0.05$ for C1). Organic matter, CP and GE intake were not affected by cottonseed nor the inclusion of vitamin E ( $p>0.05$ for Treat). Dry matter, crude protein, ether extract, organic matter, non-fibercarbohydrates and gross energy excretion were no different between the treatments, which resulted in similar excretion ( $p>0.05$ for treat). Animals fed with cottonseed had higher NDF (34 \%) and higher ADF (26\%) excretion when compared to the control. The inclusion of cottonseed improved the digestibility of EE by $14 \%$ and decreased the digestibility of NFC by $9.0 \%$. No ef- fects were observed on the digestibility of DM, $\mathrm{CP}, \mathrm{NDF}$, $\mathrm{ADF}, \mathrm{OM}$, total digestible nutrients (TDN) or GE $(p>$ 0.05 for Treat) (Table 2).

\section{Feeding behavior}

Data for the number of activities, total time per activity per day and mean time per activity are presented in Table 3. Number of meals and meal length ( $\mathrm{min}_{\text {bout }}{ }^{-1}$ ) were similar among the treatments ( $p>0.05$ for Treat). On average, animals had 6.3 visits to the feedbunk per day and spent 34.1 minutes on each meal. However, the total time spent eating was affected by cottonseed, the greatest being in animals fed cottonseed compared to the control ( $p<0.01$ for $\mathrm{C} 1 ; 217.0$ vs. $190.8 \mathrm{~min}$ ). Animals fed cottonseed had higher ruminating bout numbers per day ( $p<0.01$ for $\mathrm{C} 1 ; 16.1$ vs. 14.1$)$, spent more total time in rumination per day $(p<0.01$ for $\mathrm{C} 1 ; 433.7$

Table 2 - Nutrient intake and excretion, as well as apparent digestibility of cattle fed dietary treatments.

\begin{tabular}{|c|c|c|c|c|c|c|c|}
\hline & \multicolumn{3}{|c|}{ Treatments } & \multirow{2}{*}{ SEM } & \multicolumn{3}{|c|}{ *Probability } \\
\hline & Control & CS & CSVitE & & Treat & $\mathrm{C} 1$ & $\mathrm{C} 2$ \\
\hline \multicolumn{8}{|l|}{ Daily feed intake } \\
\hline DMI (kg) & 14.6 & 15.4 & 15.4 & 0.61 & NS & - & - \\
\hline DMI (g kg BW) & 16.6 & 17.4 & 17.4 & 0.05 & NS & - & - \\
\hline DMI (g kg-1 BW0.75) & 90.6 & 95.1 & 95.2 & 2.85 & NS & - & - \\
\hline $\mathrm{CP}(\mathrm{kg})$ & 1.78 & 2.11 & 2.12 & 0.11 & NS & - & - \\
\hline $\mathrm{EE}(\mathrm{kg})$ & 0.32 & 1.01 & 0.99 & 0.08 & $<0.01<$ & $=0.01$ & NS \\
\hline NDF (kg) & 2.76 & 4.70 & 4.63 & 0.31 & $<0.05<$ & $=0.01$ & NS \\
\hline ADF (kg) & 1.97 & 3.44 & +3.39 & 0.23 & $<0.05<$ & 0.01 & NS \\
\hline NFC (kg) & 7.98 & 4.46 & 4.51 & 0.49 & $<0.05<$ & $=0.01$ & NS \\
\hline OM (kg) & 11.5 & 12.2 & 12.2 & 0.64 & NS & - & - \\
\hline GE (MJ) & 211 & 245 & 245 & 28.0 & NS & - & - \\
\hline \multicolumn{8}{|l|}{ Daily nutrient excretion } \\
\hline DM (kg) & 3.67 & 4.02 & 4.06 & 0.19 & NS & - & - \\
\hline $\mathrm{CP}(\mathrm{kg})$ & 0.48 & 0.56 & 0.54 & 0.03 & NS & - & - \\
\hline $\mathrm{EE}(\mathrm{kg})$ & 0.06 & 0.05 & 0.06 & 0.003 & 3 NS & - & - \\
\hline NDF (kg) & 1.46 & 1.99 & 1.89 & 0.12 & $<0.05<$ & 0.05 & NS \\
\hline ADF (kg) & 1.11 & 1.68 & 31.64 & 0.11 & $<0.05<$ & $=0.05$ & NS \\
\hline NFC (kg) & 0.92 & 0.95 & 0.92 & 0.09 & NS & - & - \\
\hline $\mathrm{OM}(\mathrm{kg})$ & 3.23 & 3.57 & 3.42 & 0.20 & NS & - & - \\
\hline GE (MJ) & 67.1 & 75.9 & 72.8 & 4.30 & NS & - & - \\
\hline \multicolumn{8}{|l|}{ Nutrient digestibility } \\
\hline $\mathrm{DM}\left(\mathrm{g} \mathrm{kg}^{-1}\right)$ & 676 & 679 & 677 & 22.4 & NS & - & - \\
\hline $\mathrm{CP}\left(\mathrm{g} \mathrm{kg}^{-1}\right)$ & 707 & 727 & 732 & 19.3 & NS & - & - \\
\hline $\mathrm{EE}\left(\mathrm{g} \mathrm{kg}^{-1}\right)$ & 801 & 942 & 935 & 19.0 & $<0.05<$ & $=0.01$ & NS \\
\hline NDF $\left(\mathrm{g} \mathrm{kg}^{-1}\right)$ & 478 & 558 & 575 & 36.7 & NS & - & - \\
\hline ADF $\left(\mathrm{g} \mathrm{kg}^{-1}\right)$ & 421 & 487 & 493 & 44.4 & NS & - & - \\
\hline $\mathrm{NFC}\left(\mathrm{g} \mathrm{kg}^{-1}\right)$ & 857 & 781 & 783 & 17.1 & $<0.05<$ & $=0.05$ & NS \\
\hline $\mathrm{OM}\left(\mathrm{g} \mathrm{kg}^{-1}\right)$ & 694 & 699 & 708 & 21.9 & NS & - & - \\
\hline GE $\left(\mathrm{g} \mathrm{kg}^{-1}\right)$ & 681 & 690 & 70.2 & 23.3 & NS & - & - \\
\hline $\operatorname{TDN}^{1}\left(\mathrm{~g} \mathrm{~kg}^{-1}\right)$ & 729 & 744 & 750 & 20.4 & NS & - & - \\
\hline
\end{tabular}

$\overline{\mathrm{DMl}}=$ dry matter intake; $\mathrm{BW}=$ body weight; $\mathrm{CP}=$ crude protein; $\mathrm{EE}=$ ether extract; NDF = neutral detergent fiber; NFC = non-fiber-carbohydrates; $\mathrm{OM}=$ organic matter; GE = gross energy; TDN = total digestible nutrients; $\mathrm{SEM}=$ standard error of the mean; NS $=p>0.10$; Treat = treatment effect; $\mathrm{BW}^{0.75}$ $=$ metabolic body weight; NS = non- significant; ${ }^{1}$ TDN = \%CP(dig) + \%CNF(dig) $+\% \mathrm{NDF}(\mathrm{dig})+\mathrm{EE}(\mathrm{dig})^{\star} 2.25$; *Probability: $\mathrm{Cl}=$ contrast 1 (CS and CSVitE vs. control); C2 = contrast 2 (CS vs. CSVitE). 
vs. $291.6 \mathrm{~min})$ and in each rumination $(p<0.01$ for $\mathrm{C} 1$; 26.8 vs. $20.6 \mathrm{~min}$ ) compared to the control. Additionally, animals fed cottonseed had a higher number of chewing bouts per day ( $p<0.05$ for $\mathrm{C} 1 ; 22.9$ vs. 20.1$)$, spent more total time chewing per day $(p<0.01$ for $\mathrm{C} 1 ; 650.5$ vs. $482.5 \mathrm{~min})$ and in each chewing session $(p<0.05$ for C1; 28.6 vs. $24.1 \mathrm{~min}$ ) compared to the control diet. Idle bout numbers per day were not affected by either cottonseed or vitamin E ( $p>0.05$ for Treat), on average animals had 22.2 idle bouts per day. However, animals fed with cottonseed spent less time in idle per day $(p<0.01$ for $\mathrm{C} 1 ; 789.1$ vs. $961.6 \mathrm{~min})$ and per idle bout $(p<0.01$ for $\mathrm{C} 1 ; 45.4$ vs. $49.5 \mathrm{~min}$ ) compared to the control diet. Animals fed CSVitE diet had higher number of ruminating bouts per day ( $p<0.05$ for $\mathrm{C} 2 ; 17.1$ vs. 15.1$)$ and spent smaller time in each bout of idleness $(p<0.05$ for C2; 24.5 vs. $29.1 \mathrm{~min}$ ) compared to the CS diet (Table 3).

Adding cottonseed to the animal's diets, regardless of vitamin $\mathrm{E}$, increased the amount of time eating, ruminating and chewing and decreased idleness time $(p<$ 0.01 for C1). Animals fed with cottonseed spent $15 \%$ of the day eating, $30 \%$ ruminating and $55 \%$ in idling, and animals fed with the control diet spent $13 \%$ eating, 20 $\%$ ruminating and $66 \%$ in idling (Figure 1 ).

Dry matter intake per minute and DMI per meal were not affected by cottonseed or vitamin E supplementation ( $p>0.05$ for Treat). Animals fed cottonseed had a greater amount of NDF intake per minute $p<$ 0.01 for $\mathrm{C} 1 ; 0.022 \mathrm{vs} .0 .015 \mathrm{~kg}$ ) and the amount of NDF intake per eating bout $(p<0.05$ for $\mathrm{C} 1 ; 0.766$ vs. 0.518 $\mathrm{kg}$ bout $^{-1}$ ) compared to the control diet.

The amount of DM ruminated per minute was lower for animals fed cottonseed rather than the control

Table 3 - Meal, rumination, idles and chewing patterns of cattle influenced by cottonseed and vitamin $\mathrm{E}$.

\begin{tabular}{|c|c|c|c|c|c|c|c|}
\hline & \multicolumn{3}{|c|}{ Treatments } & \multirow{2}{*}{ SEM } & \multicolumn{3}{|c|}{ *Probability } \\
\hline & Control & CS & CSVitE & & Treat & $\mathrm{C} 1$ & $\mathrm{C} 2$ \\
\hline \multicolumn{8}{|l|}{ Eating } \\
\hline Bouts $d^{-1}$ & 6.00 & $\begin{array}{ll}0 & 6.83\end{array}$ & 36.16 & 50.31 & NS & - & - \\
\hline $\min d^{-1}$ & 190.8 & 219.1 & 215.0 & 7.49 & $<0.01$ & $<0.01$ & NS \\
\hline Length $\left(\min\right.$ bout $^{-1}$ ) & 32.4 & 33.1 & 36.9 & 1.79 & NS & - & - \\
\hline \multicolumn{8}{|l|}{ Ruminating } \\
\hline Bouts d-1 & 14.1 & 15.1 & 17.1 & 0.63 & $<0.05$ & $<0.01<$ & $<0.05$ \\
\hline $\min d^{-1}$ & 291.6 & 437.5 & 430.0 & 22.1 & $<0.01$ & $<0.01$ & NS \\
\hline Length $\left(\min\right.$ bout $^{-1}$ ) & 20.6 & 29.1 & 24.5 & 1.27 & $<0.01$ & $<0.01<$ & $<0.05$ \\
\hline \multicolumn{8}{|l|}{ Idles } \\
\hline Bouts $\mathrm{d}^{-1}$ & 21.8 & 22.3 & 22.5 & 0.45 & NS & - & - \\
\hline $\min d^{-1}$ & 961.6 & 788.3 & 799.9 & 23.0 & $<0.01$ & $<0.01$ & NS \\
\hline Length $\left(\min\right.$ bout $^{-1}$ ) & 49.5 & 45.9 & 45.0 & 1.80 & $<0.01<$ & $<0.001$ & NS \\
\hline \multicolumn{8}{|l|}{ Chewing } \\
\hline Bouts $d^{-1}$ & 20.1 & 22.0 & 23.8 & 0.66 & $<0.05$ & $<0.010$ & 0.0858 \\
\hline $\min d^{-1}$ & 482.5 & 656.6 & 645.0 & 22.8 & $<0.01$ & $<0.01$ & NS \\
\hline Length (min bout ${ }^{-1}$ ) & 24.1 & 30.0 & 27.3 & 0.96 & $<0.01$ & $<0.01$ & NS \\
\hline
\end{tabular}

$\operatorname{diet}(p<0.05$ for $\mathrm{C} 1 ; 0.036$ vs. $0.050 \mathrm{~kg})$. Amount of DM ruminating per bout and amount of NDF ruminating per minute were affected neither by cottonseed nor by the inclusion of vitamin $\mathrm{E}$ ( $p>0.05$ for Treat). However, the animals fed cottonseed had a greater amount of NDF ruminating per bout $(p<0.05$ for $\mathrm{C} 1 ; 0.297$ vs. $0.224 \mathrm{~kg}$ bout $^{-1}$ ) compared to the control (Table 4).

The amount of DM chewing per minute, DM chewing per bout and NDF chewing per minute were not affected by cottonseed nor vitamin E $(p>0.05$ for Treat). Nonetheless, the amount of NDF chewing per bout was greater for the animals fed cottonseed $(p<$ 0.01 for $\mathrm{C} 1 ; 0.200$ vs. $0.152 \mathrm{~kg}$ ) compared to the control (Table 4.)

\section{Ruminal dynamics}

Ruminal solid mass ( $p<0.01$ for $\mathrm{C} 1)$ and ruminal total mass $(p<0.05$ for $\mathrm{C} 1)$ were, respectively, $32 \%$

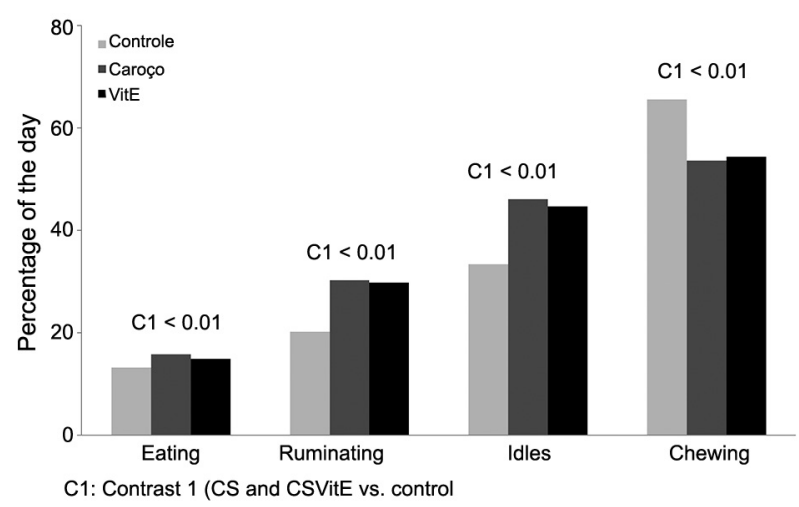

Figure $\mathbf{1}$ - Activities in percentage of the day for cattle fed different diets.

Table 4 - Effects of dietary cottonseed and vitamin E on cattle meal patterns.

\begin{tabular}{|c|c|c|c|c|c|c|c|}
\hline & \multicolumn{3}{|c|}{ Treatment } & \multirow{2}{*}{ SEM } & \multicolumn{3}{|c|}{${ }^{*}$ Probability } \\
\hline & Control & CS & CSVitE & & Treat & $\mathrm{C} 1$ & $\mathrm{C} 2$ \\
\hline \multicolumn{8}{|l|}{ Eating } \\
\hline DM $\left(\mathrm{kg} \mathrm{min}{ }^{-1}\right)$ & 0.076 & 0.072 & 0.071 & 0.003 & NS & - & - \\
\hline $\mathrm{DM}_{\text {bout }}{ }^{-1}(\mathrm{~kg})$ & 2.326 & 2.386 & 2.630 & 0.179 & NS & - & - \\
\hline NDF $\left(k g \min ^{-1}\right)$ & 0.015 & 0.022 & 0.022 & 0.001 & $<0.01$ & $<0.01$ & NS \\
\hline NDF bout ${ }^{-1}(\mathrm{~kg})$ & 0.518 & 0.729 & 0.803 & 0.057 & $<0.05$ & $<0.05$ & $<0.01$ \\
\hline \multicolumn{8}{|l|}{ Ruminating } \\
\hline $\mathrm{DM}\left(\mathrm{kg} \mathrm{min}{ }^{-1}\right)$ & 0.050 & 0.036 & 0.036 & 0.003 & $<0.05$ & $<0.05$ & NS \\
\hline DM bout $^{-1}(\mathrm{~kg})$ & 1.006 & 1.058 & 0.891 & 0.077 & NS & - & - \\
\hline NDF $\left(\mathrm{kg} \mathrm{min}{ }^{-1}\right)$ & 0.011 & 0.011 & 0.011 & 0.000 & NS & - & - \\
\hline NDF bout ${ }^{-1}(\mathrm{~kg})$ & 0.224 & 0.323 & 0.272 & 0.022 & $<0.05$ & $<0.05$ & NS \\
\hline \multicolumn{8}{|l|}{ Chewing } \\
\hline $\mathrm{DM}\left(\mathrm{kg} \mathrm{min}^{-1}\right)$ & 0.030 & 0.024 & 0.023 & 0.001 & NS & - & - \\
\hline DM bout $^{-1}(\mathrm{~kg})$ & 0.686 & 0.724 & 0.656 & 0.046 & NS & - & - \\
\hline NDF (kg min-1) & 0.006 & 0.007 & 0.007 & 0.001 & NS & - & - \\
\hline NDF bout ${ }^{-1}(\mathrm{~kg})$ & 0.152 & 0.221 & 0.200 & 0.014 & $<0.05$ & $<0.01$ & NS \\
\hline
\end{tabular}


and $8 \%$ greater for the animals fed cottonseed than the animals fed the control diet respectively (Table 5). When ruminal mass was expressed in relation to body weight, animals fed with cottonseed had $30 \%$ greater ruminal solid mass than the control diet $(p<0.01$ for C1) (Table 5). Solid disappearance was $20 \%$ lower when expressed in percentage per hour $(p<0.01$ for $\mathrm{C} 1)$ and $10 \%$ greater when expressed in kilograms per hour $(p<0.05$ for C1) for animals fed cottonseed than those fed the control diet (Table 5).

\section{Ruminal parameters}

Animals fed the cottonseed diet had higher mean $(p<0.05$ for $\mathrm{C} 1 ; 6.69$ vs. 6.39$)$, maximum $(p<0.05$ for $\mathrm{C} 1 ; 7.2 \mathrm{vs}$. 6.94) and minimum $(p<0.05$ for $\mathrm{C} 1 ; 6.15$ vs. 5.83) ruminal $\mathrm{pH}$ levels compared to the control animals fed the control diet (Table 6). No differences across treatments were observed for the time the $\mathrm{pH}$ remained below 5.8 and 6.0 regardless of treatment $(p>0.05$ for

Table 5 - Ruminal liquid, solid and total content, as well as solid disappearance rate of cattle fed cottonseed or vitamin $\mathrm{E}$.

\begin{tabular}{|c|c|c|c|c|c|c|c|}
\hline & \multicolumn{3}{|c|}{ Treatments } & \multirow{2}{*}{ SEM } & \multicolumn{3}{|c|}{${ }^{*}$ Probability } \\
\hline & Control & CS & CSVitE & & Treat & $\mathrm{C} 1$ & $\mathrm{C} 2$ \\
\hline RLM (kg) & 49.4 & 52.2 & 50.9 & 1.70 & NS & - & \\
\hline RSM (kg) & 8.29 & 10.8 & 11.2 & 0.45 & $<0.01$ & $<0.01$ & NS \\
\hline RTM (kg) & 57.7 & 63.0 & 62.1 & 1.97 & $<0.05$ & $<0.05$ & NS \\
\hline RLMBW0.75 $\left(\mathrm{g} \mathrm{kg}^{-1}\right)$ & 57.7 & 59.5 & 58.4 & 1.60 & NS & - & - \\
\hline $\mathrm{RSMBW}^{0.75}\left(\mathrm{~g} \mathrm{~kg}^{-1}\right)$ & 9.70 & 12.5 & 12.8 & 0.50 & $<0.01$ & $<0.01$ & NS \\
\hline RTMBW $^{0.75}(\mathrm{~kg})$ & 67.4 & 72.0 & 71.3 & 1.90 & NS & - & - \\
\hline $\mathrm{RSD}\left(\mathrm{g} \mathrm{kg} \mathrm{h}{ }^{-1}\right)$ & 73.3 & 59.4 & 57.2 & 2.80 & $<0.01$ & $<0.01$ & NS \\
\hline RSD $\left(\mathrm{kg} \mathrm{h}^{-1}\right)$ & 0.60 & 0.66 & 0.66 & 0.02 & $<0.05$ & $<0.05$ & NS \\
\hline $\begin{array}{l}\text { RLM = ruminal liqu } \\
\text { total mass; RLMBW } \\
\text { weight; RSMBW } 0.75= \\
\text { RTMBW. }=75=\text { rumina } \\
\text { ruminal solid disapp } \\
>0.10 \text {; Treat = treat } \\
\text { vs. control); } \mathrm{C} 2=\text { co }\end{array}$ & $\begin{array}{l}\text { uminal } \\
\text { otal ma } \\
\text { rance r } \\
\text { ent effe }\end{array}$ & $\begin{array}{l}\text { olid ma } \\
\text { ss in re } \\
\text { te; SEn } \\
\text { t; *Po }\end{array}$ & $\begin{array}{l}\text { ass in } \\
\text { Iation } \\
\\
\text { b = sta } \\
\text { bability }\end{array}$ & & $\begin{array}{l}\text { neta } \\
\text { c boc } \\
r \text { of }\end{array}$ & $\mathrm{M}$ & $\begin{array}{l}\text { eight } \\
\text { RSD }\end{array}$ \\
\hline
\end{tabular}

Treat). For the cows fed cottonseed the $\mathrm{pH}$ remained less time below 6.2 ( $p<0.05$ for $\mathrm{C} 1 ; 84.3$ vs. $410 \mathrm{~min}$ ) compared to the control (Table 6). Regardless of treatment no difference was observed for the acetate concentration ( $p>0.05$ for Treat). Cows fed cottonseed had higher propionate concentration $(p<0.01$ for $\mathrm{C} 1 ; 20.8$ vs. 15.2 mmol L-1) compared to the control. However, a lower butyrate concentration $(p<0.01$ for $\mathrm{C} 1$; 9.2 vs. 12.7 $\left.\mathrm{mmol} \mathrm{L})^{-1}\right)$ and acetate to propionate ratio $(p<0.01$ for $\mathrm{C} 1 ; 3.3$ vs.4.7) were observed for the cows fed cottonseed compared to the control diet (Table 6).

\section{Discussion}

\section{Nutrient intake, excretion and digestibility}

The negative effects of lipid supplementation on DMI have been reported in some (Harvatine and Allen, 2006; Martin et al., 2008) but not all studies (Johnson et al., 2002; Moate et al., 2011). Dry matter intake depression can be expected when the dietary fat concentration exceeds $6 \%$ (Beauchemin et al., 2007). However, in the present study $8 \%$ of fatty concentration was added and there was no difference in DMI across treatments. This is in agreement with Sullivan et al. (2004) in which lactating Holstein animals were fed diets containing cottonseed (63.0 $\mathrm{g} \mathrm{EE} \mathrm{kg}^{-1} \mathrm{DM}$ ) and consumed similar amounts of DM. Jorge et al. (2008) added $150 \mathrm{~g} \mathrm{~kg}^{-1}$ of cottonseed (57.7 $\mathrm{g} \mathrm{EE} \mathrm{kg}^{-1} \mathrm{DM}$ ) and observed that the use of cottonseed did not affect DMI.

In the present study it is likely that the capacity of the microorganism to saturate the unsaturated fatty acids was not exceeded. Thus, unsaturated fatty acids were not accumulated, resulting in regular microbial digestion and DMI (NRC, 2001). The mechanisms of reduced DMI caused by lipid supplementation are related to the biohydrogenation process of unsaturated fatty acids in the rumen (NRC, 2001). Negative effects of lipids on bacterial growth increases with the degree of unsaturation of fatty acids (Giger-Reverdin et al., 2003).

Table 6 - Ruminal parameters of non-lactating animals fed dietary treatments.

\begin{tabular}{|c|c|c|c|c|c|c|c|c|c|}
\hline & \multicolumn{3}{|c|}{ Treatments } & \multirow{2}{*}{ SEM } & \multicolumn{5}{|c|}{ Probability } \\
\hline & Control & CS & CSVitE & & Treat & $\mathrm{C} 1$ & $\mathrm{C} 2$ & Time & ${ }^{\star} \mathrm{T} \times \mathrm{Ti}$ \\
\hline \multicolumn{10}{|l|}{ Ruminal pH } \\
\hline Mean & 6.39 & 6.77 & 6.62 & 0.07 & $<0.05$ & $<0.05$ & NS & - & - \\
\hline Maximum & 6.94 & 7.26 & 7.14 & 0.06 & $<0.05$ & $<0.05$ & NS & - & - \\
\hline Minimum & 5.83 & 6.26 & 6.05 & 0.09 & $<0.05$ & $<0.05$ & NS & - & - \\
\hline Time $\mathrm{pH}<5.8$ (min) & 128.3 & 0.00 & 51.7 & 43.0 & NS & - & - & - & - \\
\hline Time $\mathrm{pH}<6.2$ (min) & 410.0 & 26.7 & 142 & 68.1 & $<0.05$ & $<0.05$ & NS & - & - \\
\hline \multicolumn{10}{|l|}{ SCFA concentration } \\
\hline Acetate $\left(\mathrm{mmol} \mathrm{L}^{-1}\right)$ & 71.13 & 67.23 & 67.12 & 0.897 & NS & - & - & $<0.05$ & NS \\
\hline Propionate mmol $\mathrm{L}^{-1}$ ) & 15.25 & 20.75 & 20.94 & 0.499 & $<0.01$ & $<0.01$ & NS & $<0.01$ & NS \\
\hline Butirate $\left(\mathrm{mmol} \mathrm{L}^{-1}\right)$ & 12.71 & 9.346 & 9.129 & 0.293 & $<0.01$ & $<0.01$ & NS & 0.0591 & NS \\
\hline C2:C3 ratio & 4.766 & 3.294 & 3.349 & 0.098 & $<0.01$ & $<0.01$ & NS & $<0.01$ & NS \\
\hline
\end{tabular}

SCFA = short chain fatty acids; $\mathrm{C} 2: \mathrm{C} 3$ ratio = acetate to propionate ratio; $\mathrm{SEM}=$ standard error of the mean; $\mathrm{NS}=p>0.10 ; \mathrm{Treat}=$ treatment effect; ${ }^{\star} \mathrm{T} \times \mathrm{Ti}=$ interaction treatment and time; *Probability: $\mathrm{C} 1$ = contrast 1 (CS and CSVitE vs. control); C2 = contrast 2 (CS vs. CSVitE). 
According to Jenkins and Lundy (2001) whole oilseeds lessen the severity of digestion problems by encapsulation of anti-microbial fatty acids within their hard outer seed coat. Data reported by Oliveira et al. (2007) proves this. The authors evaluated the effects of different dietary lipid sources (soybean grain and soybean oil with $62.0 \mathrm{~g} \mathrm{EE} \mathrm{kg}^{-1} \mathrm{DM}$ and $55.4 \mathrm{~g} \mathrm{EE} \mathrm{kg}^{-1} \mathrm{DM}$ respectively) on the intake in buffalo bulls fed a high-concentrate diet. They observed that when soybean oil was added there was a decrease in DMI compared to the control. However, when the source was soybean grain there was no difference in DMI compared to the control.

In the present study, similar digestibility in NDF and ADF were observed among treatments. It is in agreement with Jorge et al. (2008) added $150 \mathrm{~g} \mathrm{~kg}^{-1}$ of cottonseed (57.7 g EE kg DM) observed that the use of cottonseed did not affect fiber digestibility. Patra et al. (2013) in a meta-analysis study concluded that fat supplementation in the form of oilseeds has less of a negative effect on fiber digestibility than oil supplementation. These authors observed similar NDF digestibility when oilseeds were compared to the control. However, lower NDF digestibility was observed when oils were compared to the control.

As expected, the inclusion of cottonseed inclusion results in higher NDF intake and according to NRC (2001), the NDF content of cottonseed has $100 \%$ effectiveness. Physically effective fiber is the fraction of the feed that stimulates chewing; chewing stimulates saliva secretion, which buffers acidic end products of fermentation and helps prevent depressions in DMI and fiber digestibility (Allen, 1997). As observed, cows fed cottonseed had higher chewing activity (Table 3 and Figure 1) and higher mean, minimum and maximum $\mathrm{pH}$ compared to the control diet and it contributed to canceling out the negatives effects of lipid on DMI and fiber digestibility. According to Bateman and Jenkins (1998), when there is adequate NDF content the use of diets containing up to $70 \mathrm{~g} \mathrm{~kg}^{-1}$ of soybean oil has no consequences for nutrient digestibility. Reduction in fiber digestion at low $\mathrm{pH}$ is likely the result of a reduction in the growth or activity of ruminal cellulolytic bacteria (Grant and Mertens, 1992; Russell and Dombrowski, 1980).

In relation to vitamin $\mathrm{E}$, the present experiment is an in vivo study and the data are in disagreement with in vitro studies. Vásquez-Anon and Jenkinst (2007) using fresh oil and oxidized oil observed that a blend of antioxidant (200 $\mathrm{mg} \mathrm{kg}^{-1}$ ) improved the total carbohydrate, $\mathrm{NDF}$ and ADF digestibility regardless of the type of fat. Smith et al. (2002) feeding $50 \mathrm{mg} \mathrm{kg}{ }^{-1}$ of antioxidant (ethoxyquin) in dairy cows observed improvements in OM digestibility, suggesting an antioxidant effect on rumen fermentation.

In spite of the high level of cottonseed inclusion, it may not have been enough to release significant amount of free radicals within the rumen to induce oxidative stress in the rumen, since no negative effect on the presence of unsaturated fatty acids in the rumen was verified when compared with the cottonseed treatments in relation to the control treatment. According to Vásquez-Anon and Jenkinst (2007), the mechanism by which antioxidant compounds meliorate the toxic effect of excessive unsaturated fatty acids has not been well depicted and might vary with the antioxidant compound and type of fat.

\section{Feeding behavior}

The inclusion of cottonseed increased total eating and ruminating time (Figure 1), reflecting the increased time it took animals to chew and reduce idling. Longer eating time when expressed in minutes per day (Table 3) is likely due to higher fiber intake and some difficulty that the cows fed cottonseed had when ingesting the total mixed ration (TMR). Our results are consistent with the report of Kahyani et al. (2012) who indicated that the increase in eating time was partially a result of higher NDF intake and Nasrollahi et al. (2012) also observed that higher physically effective NDF intake resulting in an increase in eating time. Additionally, according to Beauchemin (1991) characteristics of eating time are impacted mainly by physical factors that affect ease of ingestion. Longer eating time associated with similar DMI and higher NDF intake should correspond to a slower DM eating rate ( $\mathrm{kg}$ of DM min $\left.{ }^{-1}\right)$ and similar NDF eating rate ( $\mathrm{kg}$ of $\left.\mathrm{NDF} \mathrm{min}^{-1}\right)$. However, in the present study the longer eating time was not enough to reduce the DM eating rate and equalize the NDF eating rate, thus were observed no differences for the DM eating rate and higher NDF eating rate (Table 4) were observed. These results are in agreement with Kargar et al. (2010), who observed DMI was not affected by fat supplementation and that the time spent for eating expressed as $\mathrm{kg}$ DM per minute was similar among treatments.

Longer time spent ruminating when expressed in number of ruminating, minutes per day and minutes per bout (Table 3) is likely due to higher NDF supply for the cows fed cottonseed and lipid inclusion has less effect on this. As suggested by Mertens (1997) and Nørgaard et al. (2010), the intake of forage NDF (physical effective fiber) is the major driver for daily time spent rumination and according to Kargar et al. (2010) fat supplementation minimal effects on rumination pattern. These results are consistent with Iraira et al. (2013) who observed that due to the higher NDF intake of heifers fed cottonseed spent more time eating, ruminating and chewing. These results can prove that the effectiveness of NDF of cottonseed is equally effective independent of forage fiber source. Clark and Armentano (1993) confirmed this, when cottonseed was compared to alfalfa haylage in lactating dairy animals fed a diet with a 30:70 forage to concentrate ratio, both diets having a similar performance. As expected, similar DMI and higher NDF intake (Table 2) associated with longer ruminating time (Table 3) corresponded to slower ruminating time adjusted by DMI ( $\mathrm{kg}$ of $\mathrm{DM} \mathrm{min}^{-1}$ ) and similar ruminating time adjusted by NDF intake (kg of NDF $\mathrm{min}^{-1}$ ) (Table 4). 
Regardless of treatments, the animals had the same behavior pattern, spending most of the time idling, following rumination and eating sessions (Figure 1). Eating, ruminating and idling distribution patterns over 24 hours were similar among treatments (Figure 2). During the diurnal period (06h00 to 18h00) animals spent most of their time eating, $89 \%, 87 \%$ and $91 \%$ of day for the control, CS and CSVitE groups respectively. In fact, eating peaks occurred after fresh food was placed in front of the animals at $08 \mathrm{~h} 00$ and $16 \mathrm{~h} 00$ (Figure 2). For all treatments at the two hour after morning offering $(08 \mathrm{~h} 00$ to $10 \mathrm{~h} 00)$, the animals spent $36 \%, 31 \%$ and $32 \%$ of their total time eating, for the control, CS and CSVitE respectively.

For two hours after at the afternoon offering (between $16 \mathrm{~h} 00$ and 18h00), animals spent $28 \%, 27$ $\%$ and $30 \%$ of their total time eating. Thus, two hours after animals being fed $108 \mathrm{~h} 00$ to $10 \mathrm{~h} 00$ and $16 \mathrm{~h} 00$ to $18 \mathrm{~h} 00$ ) corresponded to $65 \%, 59 \%$ and $63 \%$ of the total time spent eating during the $24 \mathrm{~h} 00$ periods for the control, CS and CSVitE, respectively. Our data are similar to those observed by Dürst et al. (1993). According to these authors, offering fresh feed is a strong stimulus for feeding, resulting in around $70 \%$

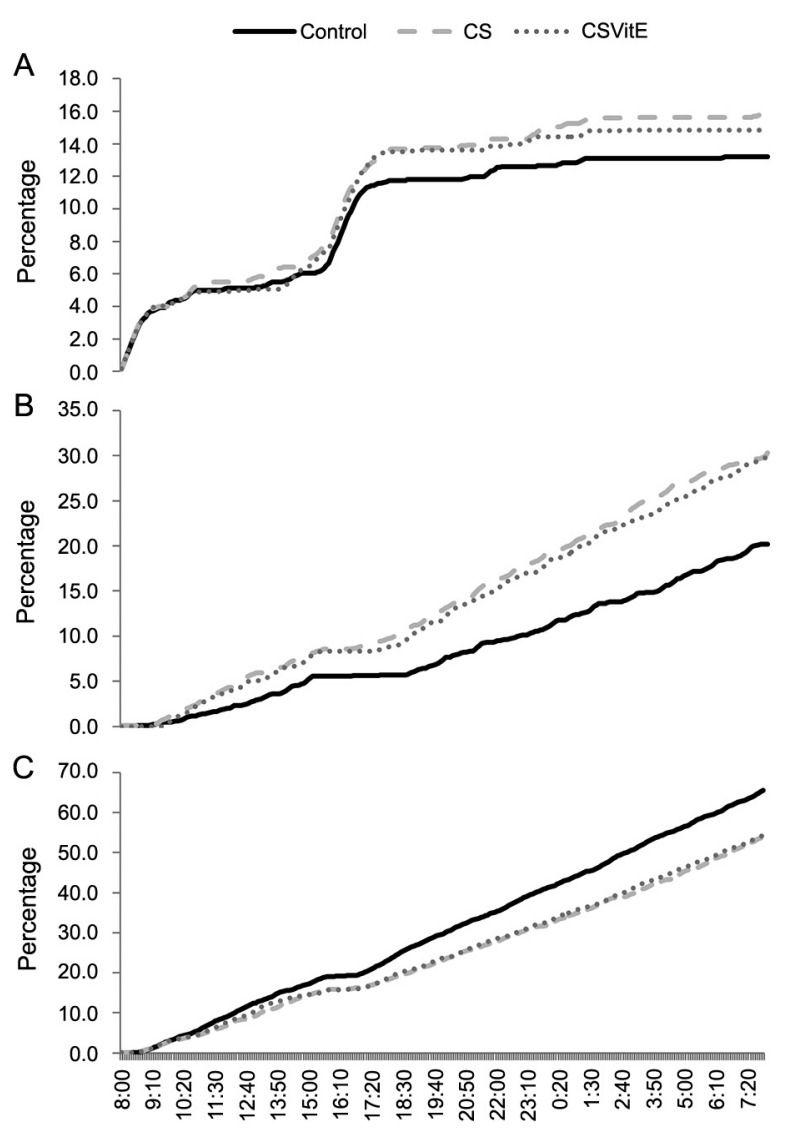

Figure 2 - Cumulative time spent eating $(A)$, ruminating $(B)$ and in idleness $(C)$ over 24 hours for cattle fed cottonseed and vitamin $E$. of the daily total proportion of intake being consumed immediately after offering. Ruminating activity was prevalent during the night period (18h00 to 06h00), corresponding to $69 \%, 60 \%$ and $62 \%$ of the total ruminating time in a $24 \mathrm{~h} 00$ period for the control, CS and CSVitE groups, respectively. This is in agreement with Adin et al. (2009), according to whom rumination peaks occurred mostly late at night and at least an hour after the eating peaks during the daytime. Idling activity was well divided between day and night (Figure 2).

\section{Ruminal Dynamics}

Ruminal solid and liquid mass data obtained in the present study are in agreement with Reynolds et al. (2004), who reported mean ruminal solid mass of $8.5 \mathrm{~kg}$ with variations from 7.1 to $10.3 \mathrm{~kg}$ and mean liquid mass of $52.6 \mathrm{~kg}$ with variations from 48.9 to 57.7 $\mathrm{kg}$. Park et al. (2011) observed a minimum liquid mass of $44.2 \mathrm{~kg}$ and maximum of $66.0 \mathrm{~kg}$, minimum solid mass of $6.1 \mathrm{~kg}$ and maximum of $11.4 \mathrm{~kg}$, and for the total mass the minimum was $50.3 \mathrm{~kg}$ and maximum was $77.4 \mathrm{~kg}$. Increased ruminal solid mass and ruminal total mass for the cows fed cottonseed appeared to have stimulated tension receptors (Allen, 2000) or provided enough tactile stimulation to increase ruminating time (Figure 1). Consequently, more solid mass remained in the rumen of animals fed cottonseed when compared to the control and lower solid disappearance rate $/ \mathrm{g}$ $\mathrm{kg} \mathrm{h}^{-1}$ ) resulting in higher solid content in the rumen for animals fed cottonseed compared to the control. Our results support the suggestion that cottonseed is retained in the ruminal mat through entanglement of cottonseed linters with longer forage particles, which would slow the solid disappearance rate (Coppock et al., 1985).

\section{Ruminal parameters}

Replacing starch with fat explains the higher $\mathrm{pH}$ of cottonseed when compared to the control diet in this experiment. Dietary content of NFC was reduced by $197 \mathrm{~g} \mathrm{~kg}^{-1}$ of DM in the cottonseed diets, and the increased ruminal $\mathrm{pH}$ in $\mathrm{CS}$ and CSVitE reflected smaller NFC intakes compared to the control diet. In addition, the highest ruminal $\mathrm{pH}$ from the cottonseed diet may also be partially explained by higher NDF content. According to Beauchemin et al. (2008), the NDF stimulates the time that animals spend chewing, thus producing more saliva and improving buffer $\mathrm{pH}$ in the rumen. Nasrollahi et al. (2012) showed that marginal increases in NDF have significant effects on feeding behavior and ruminal $\mathrm{pH}$.

The SCFA proportion was different across treatments. When cottonseed was added cows had a higher propionate proportion and lower butyrate proportion. The higher propionate proportion for the cottonseed treatments is surprising. This is supported by the observed reduction in NFC digestion and increase in fiber digestion, and, therefore, acetic acid 
proportion was expected to increase as observed by Sullivan et al. (2004) who found the acetate molar proportion and the acetate to propionate ratio increased linearly with increased dietary free fatty acids from whole cottonseed. Indeed, changes in normal ruminal fermentation patterns due to the toxic effect of unsaturated fatty acids in the rumen (Yang et al., 2009) decrease fiber digestibility (Jenkins, 1993) unlike results observed in the present experiment.

Propionate proportion increased, which probably caused from channeling of excess and reduced nicotinamide adenine dinucleotide (NADH) to propionate production owing to increased accumulation of hydrogen resulting from the inhibition of methanogens in the rumen (Patra and $Y u, 2012$ ). A decrease in butyrate percentage due to increasing inclusion of fat may be related to the defaunation effect of fats or inhibition of major butyrate producer Butyrivibrio fibrisolven (Hristov et al., 2009; Yang et al., 2009). Present data are in agreement with Iraira et al. (2013), who observed that acetate and butyrate proportions were lower and the propionate proportion was higher in beef heifers fed dietary cottonseed (160 g $\mathrm{km}$ of $\mathrm{DM}^{-1}$ ) compared to the control. Patra et al. (2014) in a meta-analysis study showed that the proportion of acetate did not change significantly with increasing concentrations of fat in diets.

In the present study, vitamin $\mathrm{E}$ had no effect on the SCFA proportion, and this is in disagreement with in vitro studies. Naziroğlu et al. (2002) supplemented $0.4 \mathrm{mg}$ and $0.8 \mathrm{mg}$ of vitamin $\mathrm{E}$ in $100 \mathrm{~mL}$ rumen fluid and they observed that the inclusion of vitamin $\mathrm{E}$ increased acetic and propionate concentration and decreased the butyrate concentration. Whey et al. (2015) added 0, 7.5, 15, 30 IU vitamin $\mathrm{E} \mathrm{kg}^{-1}$ of DM in a vitro trial and observed that supplementing vitamin E increased total SCFA and propionate and also tended to increase acetate production $(p=0.084)$.

\section{Conclusion}

Cottonseed is a recommended feedstuff for cattle when the goal is to provide high lipid concentrations. Their inclusion has positive consequences for ingestive behavior and ruminal parameters and it causes no impairment to DMI or nutrient digestibility. The inclusion of vitamin $\mathrm{E}$ combined with oilseeds is not advisable when the aims are improvements in nutrient digestibility and ruminal parameters. Further studies are encouraged to evaluate levels of vitamin $\mathrm{E}$ in association with different lipid sources and amounts.

\section{Acknowledgments}

The authors thank the Fundação de Amparo à Pesquisa do Estado de São Paulo (FAPESP) for providing scholarships and financial support. This work was supported by FAPESP grant number: 2015/11983-5.

\section{Authors' Contributions}

Conceptualization: Nogueira, R.G.S., Rodrigues, P.H.M., Pereira, A.S.C. Data acquisition: Nogueira, R.G.S., Junior, F.P. Data analysis: Nogueira, R.G.S., Rodrigues, P.H.M., Junior, F.P. Design of methodology: Nogueira, R.G.S., Rodrigues, P.H.M. Writing and editing: Nogueira, R.G.S., Rodrigues, P.H.M., Pereira, A.S.C.

\section{References}

Allen, M.S. 1997. Relationship between fermentation acid production in the rumen and the requirement for physically effective fiber. Journal of Dairy Science 80: 1447-1462. DOI: 10.3168/jds.S0022-0302(97)76074-0

Allen, M.S. 2000. Effects of diet on short-term regulation of feed intake by lactating dairy cattle. Journal of Dairy Science 83: 1598-1624. DOI: 10.3168/jds.S0022-0302(00)75030-2

Adin, G.; Solomon, R.; Nikbachat, M.; Zenou, A.; Yosef, E.; Brosh, A.; Miron, J. 2009. Effect of feeding cows in early lactation with diets differing in roughage-neutral detergent fiber content on intake behavior, rumination, and milk production. Journal of Dairy Science 92: 3364-3373.

Association of Official Analytical Chemists [AOAC]. 1995. Official Methods of Analysis. AOAC, Arlington, VA, USA.

Bateman, H.G.; Jenkins, T.C. 1998. Influence of soybean oil in high fiber diets fed to nonlactating cows on ruminal unsaturated fatty acids and nutrient digestibility. Journal of Dairy Science 81: 2451-2458. DOI: 10.3168/jds.S00220302/98/701365

Beauchemin, K.A. 1991. Effects of dietary neutral detergent fiber concentration and alfalfa hay quality on chewing, rumen function, and milk production of dairy cows. Journal of Dairy Science 74: 3140-3151.

Beauchemin, K.A.; Kreuzer, M.; O'Mara, F.; McAllister, T.A. 2008. Nutritional management for enteric methane abatement: a review. Australian Journal of Experimental Agriculture 48: 21-27. DOI: 10.1071/EA07199

Beauchemin, K.A.; McGinn, S.M.; Petit, H.V. 2007. Methane abatement strategies for cattle: lipid supplementation of diets. Canadian Journal of Animal Science 87: 431-440.

Burger, J.; Safina, C.; Gochfeld, M. 2000. Factors affecting vigilance in springbok: importance of vegetative cover, location in herd, and herd size. Acta Ethologica 2: 97-104. DOI: 10.1007/ s102119900013

Clark, P.W.; Armentano, L.E. 1993. Effectiveness of neutral detergent fiber in whole cottonseed and dried distillers grains compared with alfalfa haylage. Journal of Dairy Science 76: 2644-2650. DOI: 10.3168/jds.S0022-0302(93)77600-6

Conceição, L.E.C.; Morais, S.; Ronnestad ,I. 2007. Tracers in fish larvae nutrition: a review of methods and applications. Aquaculture 267: 62-75. DOI: 10.1016/j. aquaculture.2007.02.035

Coppock, C. E.; Moya, J.R.; West, J.W.; Nave, D.H.; Labore, J.M.; Gates, C.E. 1985. Effect of lint on whole cottonseed passage and digestibility and diet choice on intake of whole cottonseed by Holstein cows. Journal of Dairy Science 68: 1198-1206. 
DePeters, E.J.; Cant, J.P. 1992. Nutritional factors influencing the nitrogen composition of bovine milk: a review. Journal of Dairy of Science 75: 2043-2070.

Dado, R.G.; Allen, M.S. 1995. Intake limitations, feeding behaviour, and rumen function of cows challenged with rumen fill from dietary fiber or inert bulk. Journal of Dairy Science 78: 118-133.

Dürst, B.; Senn, M.; Langhans, W. 1993. Eating patterns of lactating dairy-cows of 3 different breeds fed grass ad-lib. Physiology and Behavior 54: 625-631. DOI: 10.1016/00319384(93)90069-R

Erwin, E.; Marco, S.G.J.; Emery, E.M. 1961. Volatile fatty acids analyses of blood and rumen fluid by gas chromatography. Journal of Dairy Science 44: 1768-1771. DOI: 10.3168/jds. S0022-0302(61)89956-6

Grainger, C.; Beauchemin, K.A. 2011. Can enteric methane emissions from ruminants be lowered without lowering their production? Animal Feed Science and Technology 167: 308320. DOI: $10.1016 / \mathrm{j}$.anifeedsci.2011.04.021

Giger-Reverdin, S.; Morand-Fehr, P.; Tran, G. 2003. Literature survey on the influence of dietary fat composition on methane production in dairy cattle. Livestock Production Science 82: 71-79.

Grant, R.H.; Mertens, D.R. 1992. Influence of buffer $\mathrm{pH}$ and raw corn starch addition on in vitro fiber digestion kinetics. Journal of Dairy Science 75: 2762-2768. DOI: 10.3168/jds. S0022-0302(92)78039-4

Harvatine, K.J.; Allen, M.S. 2005. The effect of production level on feed intake, milk yield, and endocrine responses to two fatty acid supplements in lactating cows. Journal of Dairy Science 88: 4018-4027. DOI: 10.3168/jds.S00220302(05)73088-5

Harvatine, K.J.; Allen, M.S. 2006. Effects of fatty acid supplements on feed intake, and feeding and chewing behavior of lactating dairy cows. Journal of Dairy Science 89: 1104-1112. DOI: 10.3168/jds.S0022-0302(06)72178-6

Hino, T.; Andoh, N.; Ohgi, H. 1993. Effects of $\beta$-carotene and $\alpha$-tocopherol on rumen bacteria in the utilization of long-chain fatty acids and cellulose. Journal of Dairy Science 76: 600-605. DOI: 10.3168/jds.S0022-0302(93)77380-4

Hristov, A.N.; Vander Pol, M.; Agle, M.; Zaman, S.; Schneider, C.; Ndegwa, P.; Vaddella, V.K.; Johnson, K.; Shingfield, K.J.; Karnati, S.K.R. 2009. Effect of lauric acid and coconut oil on ruminal fermentation, digestion, ammonia losses from manure, and milk fatty acid composition in lactating cows. Journal of Dairy Science 92: 5561-5582.

Iraira, S.P.; Ruíz de la Torre, J.L.; Rodrigues Prado, M.; Calsamiglia, S.; Manteca, X.; Ferret, A. 2013 Feed intake, ruminal fermentation, and animal behavior of beef heifers fed forage free diets containing nonforage fiber sources. Journal of Animal Science 91: 3827-3835. DOI: 10.2527/jas.2012-5803

Jenkins, T.C. 1993. Lipid metabolism in the rumen. Journal of Dairy Science 76: 3851-3863.

Jenkins, T.; Lundy, F. 2001 Feeding various fat sources to lactating dairy cows and their effects on milk quality. Available at: http:// extension.psu.edu/animals/import/dairy/nutrition/pdf/jenkinsfat-sources-and-effects on-milkquality-2001.pdf [Accessed Mar $10,2015]$
Johnson, K.A.; Kincaid, R.L.; Westberg, H.H.; Gaskins, C.T.; Lamb, B.K.; Cronrath, J.D. 2002. The effect of oilseeds in diets of lactating cows on milk production and methane emissions. Journal of Dairy Science 85: 1509-1515. DOI: 10.3168/jds. S0022-0302(02)74220-3

Jorge, J.R.V.; Zeoula, L.M.; Prado, I.N.; Silva, R.R.; Andrade, R.V.; Prado, J.; Bublitz, E.E. 2008. Lipids in diets for Holstein steers: apparent digestibility. Revista Brasileira de Saúde e Produção Animal 9: 743-753 (in Portuguese, with abstract in English).

Kahyani, A.; Ghorbani, G. R.; Khorvash, M.; Nasrollahi, S.M.; Beauchemin, K.A. 2013. Effects of alfalfa hay particle size in high-concentrate diets supplemented with unsaturated fat: chewing behavior, total-tract digestibility, and milk production of dairy cows. Journal of Dairy Science 96: 7110-7119.

Kargar, S.; Khorvash, M.; Ghorbani, G.R.; Alikhani, M.; Yang, W.Z. 2010. Effects of dietary fat supplements and forage: concentrate ratio on feed intake, feeding, and chewing behavior of Holstein dairy cows. Journal of Dairy Science 93: 4297-4301.

Keele, J.W.; Roffler, R.E.; Beyers, K.Z. 1989. Ruminal metabolism in nonlactating cows fed whole cottonseed or extruded soybeans. Journal of Animal Science 67: 1612-1622.

Maekawa, M.; Beauchemin, K.A.; Christensen, D.A. 2002. Effect of concentrate level and feeding management on chewing activities, saliva production, and ruminal $\mathrm{pH}$ of lactating dairy cows. Journal of Dairy Science 85: 1165-1175. DOI: 10.3168/jds. S0022-0302(02)74179-9

Martin, C.; Rouel, J.; Jouany, J.P.; Doreau, M.; Chilliard, Y. 2008. Methane output and diet digestibility in response to feeding dairy cows crude linseed, extruded linseed, or linseed oil. Journal of Animal Science 86: 2642-2650. DOI: 10.2527/jas.2007-0774

Martinez, N.; DePeters, E.J.; Bath, D.L. 1991. Supplemental niacin and fat effects on milk composition of lactating Holstein cows. Journal of Dairy Science 74: 202-220.

Mertens, D.R. 1997.Creating a system for meeting the fiber requirements of dairy cows. Journal of Dairy Science 80: 14631481.

Moate, P.J.; Williams, S.R.O.; Grainger, C.; Hannah, M.C.; Ponnampalam, E.N.; Eckard, R.J. 2011. Influence of cold-pressed canola, brewers grains and hominy meal as dietary supplements suitable for reducing enteric methane emissions from lactating dairy cows. Animal Feed Science and Technology 167: 254-264. DOI: 10.1016/j.anifeedsci.2011.04.069

Nasrollahi, S.M.; Khorvash, M.; Ghorbani, G.R.; Teimouri-Yansari, A.; Zali, A.; Zebeli, Q. 2012. Grain source and marginal changes in forage particle size modulate digestive processes and nutrient intake of dairy cows. Animal 6-8: 1237-1245. DOI: 10.1017/ S1751731112000122

National Research Council [NRC]. 2001. Nutrient Requirements of Dairy Cattle. National Academy of Sciences, Washington, DC, USA.

Naziroğlu, M.; Güler, T.; Yüce, A. 2002. Effect of vitamin E on ruminal fermentation in vitro. Journal of Veterinary Medicine Series A 49: 251-255.

Nørgaard, P.; Nadeau, E.; Randby, A. 2010. A new Nordic structure evaluation system for diets fed to dairy cows: a meta-analysis. p. 112-121. In: Sauvant, D.; Van Milgen, J.; Faverdin, P.; Friggens, N., eds. Modelling nutrient digestion and utilization in farm animals. Academic Publishers, Wageningen, The Netherlands. 
Oliveira, R.L.; Assunção, D.M.P.; Barbosa, M.A.A.F.; Ladeira, M.M.; Silva, M.M.P.; Mascarenhas, A.G.; Snel-Oliveira, M.V. 2007. Effect of different fat sources on intake, digestibility and blood urea nitrogen of feedlot water buffalo steers. Brazilian Journal of Animal Science 36: 733-738 DOI: 10.1590/S151635982007000300029 (in Portuguese, with abstract in English).

Park, A.F.; Shirley, J.E.; Titgemeyer, E.C.; DeFrain, J.M.; Cochran, R.C.; Wickersham, E.E.; Johnson, D.E. 2011. Characterization of ruminal dynamics in Holstein dairy cows during the periparturient period. Journal of Animal Physiology and Animal Nutrition 95: 571-582. DOI: 10.1111/j.1439-0396.2010.01085.x

Patra, A.K. 2013. The effect of dietary fats on methane emissions, and its other effect on digestibility, rumen fermentation and lactation performance in cattle: a meta-analysis. Livestock Science 155: 244-254. DOI: 10.1016/j.livsci.2013.05.023

Patra, A.K. 2014. A meta-analysis of the effect of dietary fat on enteric methane production, digestibility and rumen fermentation in sheep, and a comparison of these responses between cattle and sheep. Livestock Science 162: 97-103.

Patra, A.K.; Yu, Z. 2012. Effects of essential oils on methane production and fermentation by, and abundance and diversity of, rumen microbial populations. Applied and Environmental Microbiology 78: 4271-4280. DOI: 10.1128/AEM.00309-12

Putnam, M. E.; Comben, N. 1987. Vitamin E. Veterinary Record 121: 541-545.

Reynolds, C.K.; Dürst, B.; Lupoli, B.; Humphries, D.J.; Beever, D.E. 2004. Visceral tissue mass and rumen volume in dairy cows during the transition period from late gestation to early lactation. Journal of Dairy Science 87: 961-971. DOI: 10.3168/ jds.S0022-0302(04)73240-3

Robinson, P.H.; Tamminga, S.; Van Vuuren, A.M. 1987. Influence of declining level offeed intake and varying the proportion of starch in the concentrate on rumen ingesta quantity, composition and kinetics of ingesta turnover in dairy cows. Livestock Production Science 17: 37-62.

Russell, J.B.; Dombrowski, D.B. 1980. Effect of $\mathrm{pH}$ on the efficiency of growth by pure cultures of rumen bacteria in continuous culture. Applied and Environmental Microbiology 39: 604-610.

Secrist, D.S.; Owens, F.N.; Gill, D.R.; Boyd, L.J.; Oldfield, J.E. 1997. Effects of vitamin $\mathrm{E}$ on performance of feedlot cattle: a review. The Professional Animal Scientist 13: 47-54.
Smith, J.L.; Sheffield, L.G.; Saylor, D. 2002. Impact of ethoxyquin on productivity of dairy cattle. Journal of Dairy Science 85: 358.

Steele, W.; Noble, R.C.; Moore, J.H. 1971. The effects of 2 methods of incorporating soybean oil into the diet on milk yield and composition in the cow. Journal of Dairy Research 38: 43-48.

Sullivan, H.M.; Bernard, J.K.; Amos, H.E.; Jenkins, T.C. 2004. Performance of lactating dairy cows fed whole cottonseed with elevated concentrations of free fatty acids in the oil. Journal of Dairy Science 87: 665-671. DOI: 10.3168/jds.S00220302(04)73209-9

United States Environmental Protection Agency (EPA). 1992. Method 7000A: Atomic Absorption Methods. EPA, Washington, DC, USA.

Van Soest, P.J.; Robertson, G.B.; Lewis, B.A. 1991. Symposium: Carbohydrate methodology, metabolism, and nutritional implications in dairy cattle. Journal of Dairy Science 74: 35833597.

Vázquez-Añón, M.; Jenkins, T. 2007. Effects of feeding oxidized fat with or without dietary antioxidants on nutrient digestibility, microbial nitrogen, and fatty acid metabolism. Journal of Dairy Science 90: 4361-4367. DOI: 10.3168/jds.2006-858

Wang, L.A.; Goonewardene, Z. 2004. The use of MIXED models in the analysis of animal experiments with repeated measures data. Canadian Journal of Animal Science 84: 1-11.

Wei, C.; Lin, S.X.; Wu, J.L.; Zhao, G.Y.; Zhang, T.T.; Zheng, W.S. 2015. Effects of supplementing vitamin $\mathrm{E}$ on in vitro rumen gas production, volatile fatty acid production, dry matter disappearance rate, and utilizable crude protein. Czech Journal of Animal Science 60: 335-341. DOI: 10.17221/8402-CJAS

Yang, S.L.; Bu, D.P.; Wang, J.Q.; Hu, Z.Y.; Li, D.; Wei, H.Y.; Zhou, L.Y.; Loor, J.J. 2009. Soybean oil and linseed oil supplementation affect profiles of ruminal microorganisms in dairy cows. Animal 3: 1562-1569.

Zakrys, P.I.; Hogan, S.A.; O'Sullivan, M.G.; Allen, P.; Kerry, J.P. 2008. Effects of oxygen concentration on the sensory evaluation and quality indicators of beef muscle packed under modified atmosphere. Meat Science 79: 648-655. DOI: 10.1016/j.meatsci.2007.10.030 